\title{
THE DECADENCE OF LAW AS A PROFESSION AND ITS GROWTH AS A BUSINESS.
}

In the evolution of human society every walk of life, whether it be that of business, the professions or labor, undergoes at times changes of so subtle and yet irresistible and conclusive a character as to permanently assume a new status in the world of men and things.

The introduction of labor saving machinery has done and is still doing this for hand labor, the advent of modern methods of transportation has revolutionized the problem of distribution and made the primitive trader into the commercial magnate.

The professions cannot remain unaffected by this evolution, which has for its keynote, economy, not merely in cost, but in the time consumed to gain results.

The legal profession, speaking broadly, is now divided into two parts, the incorporated and the unincorporated, or to put it in another way, the syndicated and the individual. And the discouraging thing about it all, to the person who would cling to the ways that are old and tried, is that the former is growing, not merely in strength. but in what is more dangerous because more permanent, in efficiency. Ten years has witnessed the rise and growth of most of these incorporated or syndicated absorbers of legal business.

They are now no longer experiments, they are fermanent parts of the economy of solidarity of modern business methods. For nearly a clecade, East and West, North and South, the legal profession has been searching for an adequate explanation and understanding of why the volume of legal business grew steadily less for the individual practitioner despite the rapid and healthy upward movement in all classes of commercial pursuits.

Bar associations have labored over the discussion of it and legal periodicals have been weighed down with elaborate presentations of all sides of this subject so vital and so fraught with peril to the profession. Some have tried to ascribe it to the general growth of decided law, claiming the constant labors of forty-five or more 
Supreme Courts, besides the United States Circuit Courts of Appeal, the Federal Supreme Court and other tribunals of high authority have so settled the law that no new questions now arise to create or foster legislation. But the untenability of this contention as an adequate explanation is readily shown when we recall that more than fifty per cent of all appeals are on matters of practice merely and not on questions involving legal principles; when we further recall that nearly as many Legislatures are biennially at work making new laws requiring consideration and construction; when we consider the inapplicability of the decisions of many states to others owing to conflict of laws; and when we consider the inception and growth of a great volume of new questions coming from the inventions and discoveries of the past few years.

Other writers have tried to show that the modern business man distrusts the jüry system and will make any sacrifice rather than submit his rights to its arbitrament, but in answer to this we san only say the Anglo-Saxon race is still the same as ever, and no Anglo-Saxon ever yields up what he beileves to be a substantial right without due process of law, which means a jury of his peers.

No, to find the true reason for the lessening of the generai volume of legal business for the individual practitioner we must look for a more subtle, a more scientific explanation.

Such explanation is found in the growth and prosperity of the incorporated or syndicated encroachers on the legal preserves.

Classified in the order of their importance they may be grouped as follows :

First. Title Insurance and abstract companies.

Second. Trust companies.

Third. Merchants' association and mercantile agencies.

Fourth. Employers' liability and accident insurance companies.

Fifth. Bond companies.

Sixth. Companies authorized to act as administrators and executors.

It is a conceded fact that before the advent of the title insurance theory, nearly a third of the profession's income came from matters directly or indirectly connected with real estate. The attorney searched the record, certified to that search and guaranteed the title and supervised both sale, purchase and mortgage; now he is fortunate if he gets a chance at any part of the transaction.

And yet where the Title Company is conservatively and intelligently managed and backed by proper financial strength it will be 
granted even by the individual attorney that its methods are more scientific, more accurate, more economical and financially safer, in other words it has come to supply an actual want in the economy of modern business. Likewise the trust companies, handling a vast aggregation of the savings and investments of the widow, the orplian and the illiterate, can at a low percentage of cost give a service so far more economical, safer and more intelligent than the individual attorney that the woncler is that they didn't arise earlier. The growth of trust companies in great financial centers like New York, with their careful and scientific management of the property of non-residents and estates is one of the marvels of the modern financial world. The collection business, once the fertile field of the young lawyer, is now almost universally handled by either comprehensive, mercantile agencies with a chain of officers and correspondents or by associations of the merchants themselves acting through a central board or managing officer under rules that forbid preferences, and by giving all members an equal or pro rata dividend do away with that "race of diligence" that the attachment law once fostered but which often resulted in expensive litigation, which the merchant of today ablors. If there is litigation now one attorney represents the many claims of association members where formerly a dozen might have found employment.

The bankruptcy law, a scientific complement of this pro rata plan of the merchants, puts the finishing touch on what little commercial business there may be outside of the associations.

Employers' liability and accident companies have arisen to cover the field of personal injuries.

Their invariable policy is to settle promptly where there is any question of liability-settlement in most cases being far below what the courts would have granted. And every settlement means a case lost to the lawyer and lessened business in the courts.

How far reaching this policy of settlement has becone has been most clearly exemplified in several street car accidents in recent years, from which not a single case appeared in the courts, notwithstanding shocking deaths and life-long injuries running into the scores.

Not only this but the financial wisdom of this policy has caused extra hazardous occupations, which cannot obtain this class of insurance, to be drawn into a similar line of procedure.

A leading railroad attorney was recently quoted as authority for the statement that his company showed a saving of many thous- 
and dollars in the first year of adoption of the settlement policy. Bond companies are a permanent addition to the certainty and economy of modern business, they lessen the volume of legal business by the very safeguards they throw about the inception of contracts, and once litigation is entered into, they deprive it of its terrors, and make that which was uncertain, certain.

All over the country the incorporated administrator and executor, operating as a department of a trust or title insurance company, is absorbing the probate business, and rightly so, because it has facilities for doing the work cheaper, more safely and more accurately; and above all things these are results which are vital to the widow and the orphan, whose little legacy that marks the dividing line between penury and comfort, is too often lost through the incompetency or dishonesty of individual fiduciaries.

Such are some of the changes that have already come to the profession of the law and the end is not yet.

It has been pertinently observed that this is the age of the salaried man and nowhere is this more clearly evidenced than in the legal profession.

The very evolution of which a brief sketch has been submitted, contributes to this result, for every one of the incorporated or syndicated absorbers of legal business must of necessity be largely operated and managed by men of legal training. One has only to visit the home office of one of these great incorporations to learn that every head of a department is a lawyer.

Not only this, but many large commercial interests operating in fields entirely removed from competition with the active practitioner maintain an exclusive legal department, presided over by a trained lawyer, whose duties are both advisory and clerical.

The lesson of the hour to the lawyer is plain: There is still legal business for individual practitioners, but the march of the incorporations cannot be stayed any more than any other of the advance movements of human progress, and the margin of individual business must steadily grow less and less as these superior agencies for doing legal business perfect their processes. The alternatives offered to the lawyer who by temperament or necessity cannot or will not abandon his profession, are either to abandon the large centers of population for the country town, where the individual practitioner is still a potent force, or accept the salary of the syndicate position with its rank equalling only that of an expert accountant or salesman perhaps, or, lastly, to recognize the changed conditions, give up some of the preconceived professional theories of his life 
work and re-organize his office on commercial lines, perfect a system in other words in his line of work, whether it be realty, probate or mercantile law or some other, whereby he can meet the competition that is daily crowding in upon him, and meet it on as nearly equal terms as possible.

In other words, the lawyer must broaden his horizon, abandon the role of merely adviser and counsel, advocate and spell-binder, and become the organizing influence not merely of his own immediate business, but of a score of contributory influences which go to make up a volume of profitable business and income.

In short, the lawyer of today, to live according to the standards of the day, must have outside interests and plenty of them, and if the progress of the "syndicated" idea goes forward, as the signs of the times inexorably indicate, the time is near at hand when the eloquent pages of his ledger will tell him that from these outside interests and associations come the major portion of his income.

Robert Treat Platt. 